\title{
TARIFF MAKING BY LOG ROLLING
}

\author{
By Guy Emerson, \\ Associate Editor, The Economic World.
}

It has been given to very few men to grasp the fundamentals of American institutions so fully and so fairly as did the distinguished author of The American Commonwealth. Lord Bryce perceived with the accuracy of a trained lawyer our national defects, while at the same time visualizing with the imagination of a poet the promise of American life. He wrote:

America has still a long vista of years stretching before her in which she will enjoy conditions far more auspicious than any European country can count upon. And that America marks the highest level, not only of material well-being, but of intelligence and happiness, which the race has yet attained, will be the judgment of those who look not at the favored few for whose benefit the world seems hitherto to have framed its institutions, but at the whole body of the people.

Much water has flowed under the bridge since these words were written. The nations of the Old World have plunged into war; and, as an accompaniment of the physical conflict, there has been a searching analysis of ideals and institutions on the part of thinking men all over the world which has not had its parallel since the Renaissance. Americans especially have been moved to an intellectual taking of stock. Our eyes have been turned inward, and we have had to decide all over again whether or not we were ready to stand forth and defend with our lives the institutions of our fathers. Brought face to face with the spectacle of a remarkably efficient autocracy, we, who have believed ourselves custodians of human liberties, have been forced once more to go to the roots of things, to live over again the great days during which the foundations of this republic were being laid, carefully, arduously, stone upon stone.

It does not seem too soon to declare that Americans of 1916 have concluded that they are ready to carry forward the institutions of Hamilton and Jefferson-that they still believe in human liberties. But out of this deep and, perhaps, somewhat bitter selfexamination has come the outstanding realization that much must 
be done, immediately done, to prove that a democracy can be efficient.

These are the considerations which go far to vitalize a present discussion of our system of government, and to render of first importance a review of the machinery with which we expect to keep our place in the van of world progress. It is the purpose of this paper briefly to discuss the perennial American problem of tariff making, and to outline a course of action in line with presentday demands of industrial preparedness and national efficiency.

By way of preface it should be stated that the present discussion does not involve the merits of the various schools of tariff thought. It seems obvious that the United States will, for many years to come, adhere to some degree of protection, whether frankly, or incidentally, through a policy of tariff for revenue only. These are political questions. The majority of the people must decide what policy they desire to follow. This majority will be reflected in the majority in Congress. It is important to note, however, that when the people have registered their will at the polls, there still remains the important task of framing a tariff accordingly. This is tariff making. It is essentially a scientific and non-political task. It is a highly technical and difficult task. The fact that it has always been handled along lines of political expediency is one of the most pregnant sources of our present lack of national efficiency.

Let us first see what is involved in the problem. In the first place the tariff involves a considerable proportion of the total revenue of the government. According to the Treasury Statement of June 30, 1915, the receipts for the fiscal year ended on that date were $\$ 695,663,190$, of which the revenue from customs contributed $\$ 209,268,107$. It is the second largest indirect tax imposed by the government. In addition to this, however, the imposition of a tax on imports bears directly or indirectly upon our entire industrial fabric. Not only is it vital to the manufacturer to know what, if any, protection he is to have against foreign competition, but he must also know, if he is to attain to his full capacity as a producer of goods to be sold in competitive markets at home and abroad, what the chances are of a continuance of the policy in force at any particular time. Uncertainty is the greatest enemy of successful business. Many manufacturers would gladly exchange a considerable portion of the protection they now have and 
which they stand in danger of losing at any moment, for a definite policy, based on ascertained facts, upon which an intelligent business campaign reaching into the future could safely be based, and in the security of which long-time undertakings and commitments could be entered upon.

Since 1890 there have been five revisions of the tariff. Each revision has been accompanied by an agitation of our entire commercial and industrial structure. None of the revisions has been generally satisfactory. Not only the manufacturers, but the laborers, farmers, merchants, bankers and the public generally have been more or less involved, and always with the result that an outcry has arisen for further change. It is an endless performance in which the actors are unskilled and the audience dissatisfied; and yet the same old play is staged over and over and over again.

It is a truism that a successful piece of work is the result of careful preparation and skillful execution. Is it not, therefore, more or less obvious why our tariffs have failed to satisfy the country? Let us examine briefly the machinery by means of which they are produced. In this connection a quotation is offered from an able paper by Mr. Henry R. Towne, formerly president of the Merchants' Association of New York. "The conditions under which this highly technical and complex subject is now dealt with," says Mr. Towne, "would be ludicrous, if they were not so utterly unfair. The members of the Congressional committees in charge of tariff revision are exceedingly busy men, each serving on other committees also, and devoting only a portion of his time to this work. Necessarily their public hearings must be limited to intermittent days, and be kept within limited hours, and yet, even ignoring these limitations, . . . . the time during which tariff bills have been considered, matured and adopted during recent years has been strikingly inadequate." Mr. Towne then points out that the entire time spent on each tariff act has not averaged more than three and one-half months. In this same connection the following statement of Mr. Franklin Pierce is pertinent:

So hasty and careless are the methods of tariff legislation that the Dingley Bill, which filled 163 printed pages and imposed duties upon more than 4,000 separate articles of import, introduced at the opening of the session in the House on March 15, 1897, was passed within less than two weeks and transmitted to 
the Senate, only 22 pages of it having been considered and discussed upon the floor of the House.

Mr. Pierce proceeds to recall the classic instance of the Canadian frog industry which, in their unreasoning haste, the legislators overlooked, with the result that the distracted customs appraisers, to repair the omission, held that frogs were poultry, and assessed duty accordingly.

To quote again from Mr. Towne's paper,

when Congress proposed to consider a revision of the present tariff schedules . . . . a card was issued by the Committee on Ways and Means inviting persons who desired to be heard to apply "to he assigned to a place on the program," and naming fourteen dates for the hearings beginning November 10 and ending December 4. Each hearing was to cover a "specific schedule" and was expected to last two days. The first two hearings covered the schedules relating to chemicals, liquors, tobacco and sugar. One hearing, that of November 25, was allotted to considering the question of duties on "metals and manufactures of," that is, practically everything composed wholly or chiefly of metal, from pig iron to pins, from steel rails to sewing machines, from jewelry to stoves, from watches to steam engines. Is it surprising that the thousands of manufacturers concerned were conspicuous by their absence from so farcical a proceeding?

Mr. Towne then quotes Senator Beveridge with regard to the striking discrepancies between the findings of the Committee of the House and those of the Senate Committee "in their attempt to deal with technical questions involving applied science in almost every department, and commerce in every branch." The following examples are typical of the varying preliminary rates fixed by the two branches upon the same article:

Borax, per lb.,

Phosphorus, per lb.,

Certain knives, per doz.,

Certain files, per doz.,

Finished lumber, per M. ft.,

Sugar cane, per cent. ad valorem,

Certain cotton cloth, per sq. yd.,

Matting, per sq. yd.,

$\begin{array}{llr}\text { House } 2 \mathrm{c.} & \text { Senate } & 5 \mathrm{c} . \\ \text { House } 20 \mathrm{c.} & \text { Senate } 10 \mathrm{c} . \\ \text { House } 75 \mathrm{c.} & \text { Senate } & \text { free } \\ \text { House } 30 \mathrm{c.} & \text { Senate } 50 \mathrm{c} . \\ \text { House } 50 \mathrm{c.} & \text { Senate } 35 \mathrm{c} . \\ \text { House } 20 \% & \text { Senate } 10 \% \\ \text { House } 8 \mathrm{c.} & \text { Senate } 6 \frac{1}{2} \mathrm{c} . \\ \text { House } 8 \mathrm{c.} & \text { Senate } 4 \mathrm{c} .\end{array}$

"The Conference Committee," Mr. Towne concludes, "which finally adjusted these differences of from 50 per cent to 150 per cent, was in session only five days."

It is needless to multiply instances of the total inadequacy and unfairness of present tariff-making methods. This inadequacy 
and unfairness is realized by the great majority of thinking men throughout the country. And in the minds of many men there is a pronounced feeling that the haphazard and dark-closet methods of framing these all-important measures afford too great an opportunity for practices not only unscientific but positively immoral. Conditions have unquestionably improved in this regard since the publication of The American Commonwealth. The following passage from that book is none the less a suggestive text for a discussion of tariff making at the present time:

The tariff on imports opens another enormous sphere in which legislative intervention affects private pecuniary interests; for it makes all the difference to many sets of manufacturers whether duties on certain classes of goods are raised, or maintained or lowered. Hence the doors of Congress are besieged by a whole army of commercial or railroad men and their agents, to whom, since they have come to form a sort of profession, the name of Lobbyists is given. Many Congressmen are personally interested, and lobby for themselves among their colleagues from the vantage-ground of their official positions.

Thus a vast deal of solicitation and bargaining goes on. Lobbyists offer considerations for belp in passing a bill which is desired or in stopping a bill which is feared. Two members, each of whom has a bill to get through, or one of whom desires to prevent his railroad from being interfered with while the other wishes the tariff on an article which he manufactures kept up, make a compact by which each aids the other. This is log-rolling: You help me to roll my $\log$, which is too heavy for my unaided strength, and I help you to roll yours.

Readers of The Annals of the American Academy of Political and Social Science will doubtless be ready to concede that public sentiment has for some time been running strongly counter to present tariff-making methods. Public-spirited men, irrespective of party affiliations, have declared against such methods; publicspirited organizations have passed resolutions condemning them; with one voice the press has ridiculed them. What may not be so generally recognized is the strong sentiment which has been gaining force within Congress itself in favor of putting an end to the present chaotic state of affairs. A few expressions from men who have actually been "through the mill" will serve to bring out this point. In a speech referred to above, Senator Beveridge said:

At the public hearings the committee rooms overflow with representatives of various interests. The private hearings are equally congested. Both are rushed and confused. At these hearings there is no time, no opportunity to go into any one subject thoroughly; no time, no opportunity to test the statements there made; no time, no opportunity, to verify a single supposed fact. The most 
honest and alert man could not possibly prevent, or even know about, incorrect statements; and the best of men might be excused from making a tariff rate which they did not intend to make, and which, had they known all the facts, they never would have made.

He then quotes a signed article by Senator Vest in which the latter says:

I look back now upon what occurred during the Wilson-Gorman bill as a nightmare, from the effects of which I have never recovered. Before the conference ended three of the conferees had broken down under the constant strain to which we were subjected.

A few more may be selected from the rapidly accumulating body of statements which seem to unite in their disapproval of present methods of tariff-making:

Congressman E. J. Hill, of Connecticut:

I hope never to see another general revision of the tariff with its consequent upheaval of our whole industrial organization, and with the abominable trading and dickering which inevitably result therefrom.

Senator Norris, of Nebraska:

The methods by which the tariff has been revised in the past are unscientific, illogical, and out of date. This applies to every tariff that has been enacted.

\section{Senator Root, of New York:}

We have been here for over three months considering and discussing and voting upon the measure of protection that it is necessary to give in order to keep alive and prosperous the business of tens of thousands of corporations engaged in the manufacture and trades affected by the protective tariff. Upon one hand we have garbled statements; upon the other equally garbled and partial statements; and no means of distinguishing the truth. We are under the necessity of proceeding by guesswork, by conjecture, always with dissatisfaction, because we recognize the chance that we have guessed wrong about whose statements came nearest to the truth.

\section{Senator Gore, of Oklahoma:}

Burke said that statesmanship is the science of circumstances. Few there are who will deny the potency of circumstances. But few there are who will deny that facts are the best touchstone upon which to try the virtue of theory; few who will assert that taxable articles can best be determined by intuition, and the rates of duties best determined by inspiration. . . . . It is no disparagement to the Congressional committee to relieve it of the toil of assembling facts, collecting and collating data. Shift that drudgery to somebody else, and allow the Congressmen the luxury of analyzing and reflecting upon the facts, to decide 
as between the old and the new system. It is not necessary to convict the old system as being the worst possible system; it is only necessary to find that the new system would be the better system. Whom has the old system satisfied? Has it satisfied the advocates of high tariff? Has it satisfied the advocates of low tariff? Has it satisfied the country? Has it insured industrial peace, and commercial progress and prosperity? Why, my friends, the most elaborate and most colossal works of fiction ever produced in the United States are the tariff hearings before the Finance Committee of the Senate, and the Ways and Means Committee of the House. As works of fancy they are unrivalled by the Rape of the Lock. As works of the imagination, they are unapproached by Paradise Lost. They have all the function of ex parte testimony on the part of interested witnesses, alternating between violent hope and violent fear. Every temptation to misstatement is present. Nearly every obligation to truth is absent, save conscience alone, and their consciences are under such perfect control.

An attempt has been made to emphasize the fact that tariff making is a most vital matter, and that it is handled in a most unsatisfactory manner. In saying this, it is fair to point out that no unreasoning attack on Congress is justified because of the situation as it now stands. Persons in a position to know declare that the Underwood Tariff Act was framed in a more conscientious manner than any act we have ever had. It is well known that the men responsible for it worked themselves to the verge of exhaustion in an attempt to produce a fair result. But the point seems to be that in striving to lay plans to make our democracy efficient we cannot rest content with the conscientious failures of amateurs. Speaking wholly without political bias, it may be stated that the Underwood Bill is calling forth the same criticism which has been so generously heaped upon its predecessors; and that the party which happened to be in power when it was enacted into law is now conscious of the need of many changes in the measure. No one would deny that if five or six of the able members of the Ways and Means Committee were to give their entire time during a number of years to the study of tariff making, they could equip themselves to treat the matter adequately. But what would their neglected constituents say? What would happen to the other business to which each leader in both chambers is obliged to attend? Obviously such a plan runs counter to the normal and reasonable course of business in a representative body. The situation, therefore, appears to be something like this: Under the Constitution, Congress is required to pass laws bearing upon taxation. The tariff is a taxation measure. The ablest Committees in Congress 
have demonstrated through three generations the fact that they were not equipped to carry out, in a manner satisfactory to the country, this duty of framing tariff acts. And the organization and duties of Congress are such that no permanent body equipped to handle the tariff ever can exist within Congress itself. Have we an instance here of an irresistible force striking an immovable body?

An effort will be made briefy to suggest a way out of this apparent impasse. The solution would seem to lie in this direction: that Congress has not discharged its whole duty to the people in merely framing a tariff act; its duty involves the framing of an adequate, scientific and non-political tariff act. If Congress, therefore, is unable to perform this duty unaided it should not attempt to delegate it, but should call to its assistance a body of men of the highest qualifications who would devote their whole time to studying the facts which properly underly all tariffs, whether high or low, together with their interrelationship, and their significance both as to domestic and as to foreign conditions, in such manner as to enable Congress to enact a law which will be in the best interests of the country as a whole. More than this, such a body would be able to keep abreast of the changing conditions at home and abroad and to enable Congress to meet new necessities as they arise, schedule by schedule, without the wholesale revision which has so long been the bug-bear of consistent progress and prosperity in the United States. Such is the plan in France, for example, where several hundred minor tariff changes have been made during the last few years-but always upon the basis of carefully ascertained facts, and in such a gradual manner that no business disturbance has been precipitated.

This suggestion appears to be gaining considerable favor throughout the United States. It appears to be the only answer to the problem. It may, therefore, be of interest to outline the best thought along the lines of a tariff board, or a tariff commission, as it has so far developed. It may be said at once that no tariff commission of the sort which the importance of the subject demands has ever existed in the United States. The commission of 1882 was created for a period of six months, during which time an independent body can hardly do more than can a Congressional committee towards producing a satisfactory tariff. The Tariff Board appointed by Mr. Taft in 1909 was not an independent commission 
established upon broad lines. The Payne-Aldrich Law provided for the establishment of minimum and maximum tariff rates, and gave authority to the President, in determining such rates, to appoint experts to assist him. Mr. Taft followed this authorization, and dubbed the experts a "Tariff Board." Congress did not feel bound to continue this body, however, and in 1912 the Chairman of the Committee on Appropriations in the House saw to it that no appropriation for salaries or expenses of the Board was authorized and it thereupon automatically ceased to exist.

It is further generally conceded that the salaries paid to $\mathrm{Mr}$. Taft's experts were not high enough to attract, in the majority of cases, men of the calibre demanded. And yet the work of that Board, so far as it went, was valuable, and was actually used and relied upon by Democratic members of the Ways and Means Committee in framing the Underwood Bill. In stating this fact, Senator Owen, of Oklahoma, in a recent address favoring a tariff commission, laid emphasis on the fact that the Committee on Banking and Currency of which he was chairman, found the report of the Monetary Commission of the greatest value in connection with the framing of the Federal Reserve Act. There seems to be no doubt in the minds of the constructive men in Congress that where an elaborate array of reliable facts is needed as a basis of legislation, the proper course is to employ the best men available in the country to devote their whole time to ascertaining those facts. Any other course would seem to be out of line with what the citizens of the United States have the right to demand.

It seems to be admitted very generally that the most important consideration in connection with all commissions is the character of the personnel. The most skillfully drafted statute providing for the establishment of a commission is hardly more valuable than waste paper if the appointments made under its authorization are mediocre. It is, therefore, a notable tendency of recent proposals for a tariff commission that they involve adequate salaries, on a par, for example, with those paid to members of the Federal Reserve Board. It has been urged further that a permanent annual appropriation be provided for, as was done in the recent Smith-Lever Agricultural Extension Act. Under such a provision, a commission cannot be cut off by the mere failure of a committee to insert the item in the annual appropriation measure. It is 
necessary for a member of Congress affirmatively to bring forward a bill cutting off the necessary funds, to get this bill through the House and the Senate, and then to get it signed by the President.

Finally, it should be said that it is not contemplated that such a commission should make recommendations to Congress as to specific rates of duty, unless called upon to do so. The commission is proposed not to supplant nor to combat, but solely to assist, Congress. Then, if the right sort of men are appointed and give their time and energy to the study of this one great subject, it will not be long before they will come to be recognized as tariff authorities, and it is the tendency of the times that when they are so recognized, they will be freely consulted and increasingly relied upon both by Congress and by the President. ${ }^{1}$

This suggestion is not a new one. But it is doubtful if there has been a time when its importance was greater. The unprecedented changes in commercial and industrial alignments, both at home and abroad, make necessary a far-seeing and statesmanlike study of national necessities. Press dispatches indicate that all the nations of Europe which will be our rivals after the war are, without exception, giving some sort of expert attention to their probable commercial needs after the war, with special reference to the framing of reciprocal tariff arrangements. We cannot afford to leave work of this sort to government bureaus, under political and temporary secretaries. What seems to be demanded is a small body of the best men available who shall consider this matter continuously, independently, and non-politically.

A great opportunity is presented to us; it may be said that a great crisis confronts us. Not our commercial prosperity alone is at stake. There is involved also the cause of democracy and liberty for which this country has stood forth as the leading champion for over a century. Great causes call for treatment along great lines. It is not solely a question of ending our log-rolling methods of tariff making. It is a question of letting the light of day into our whole governmental system; of using modern machinery to produce modern results; of ceasing to muddle along and of adopting instead adequate methods of preparedness for peace; in short, it is a question of taking the great, fundamental steps which are so potently, so immediately indicated in the process of proving that a democracy can be efficient.

1 Since this article was written a bill has been introduced in Congress by Representative Rainey, largely embodying the suggestions here made. 